\title{
IDENTIFIKASI SUB SEKTOR PERTANIAN DI EKS KARESIDENAN KEDU (PENDEKATAN MINIMUM REQUIREMENTS TECHNIQUE)
}

\author{
Dinan Azifah, Agustono, Nuning Setyowati \\ Program Studi Agribisnis Fakultas Pertanian, Universitas Sebelas Maret Surakarta \\ E-mail: dinan.azifah@gmail.com
}

\begin{abstract}
The objectives of this study are (1) identify the Agricultural sub sector of base and non-base in Kedu Residency (2) develop the Agriculture sub sector of base in Kedu Residency. The results, the food crops subsector basis in Kebumen, Magelang, Wonosobo, Temanggung. Sub Sector Crops base in Kebumen, Purworejo, Magelang, Temanggung. Livestock subsector base in Kebumen, Magelang, Wonosobo, Temanggung. Forestry subsector base in Kebumen, Purworejo, Magelang, Wonosobo. Fisheries subsector base in Kebumen, Purworejo, Magelang, Wonosobo. Food crops subsector non bases in Purworejo, plantation subsector in Wonosobo, livestock subsector in Purworejo, forestry and fisheries subsector in Temanggung. Development of food crops subsector in Kebumen to maximize production, agribusiness development in Magelang, in Wonosobo processing performed and marketing, in Temanggung the marketing of agricultural products. Development of the plantation subsector in Kebumen the development of HR trained, in Purworejo improving the marketing, in Magelang the development of conservation areas, in Temanggung increasing marketing and post-harvest processing. Development of the livestock subsector in Kebumen providing capital strengthening, in Magelang increased productivity through improved genetic quality, in Wonosobo revolsin Funds budgeted for the farm, in Temanggung increase in value-added farm. Development of the forestry subsector in Kebumen, Purworejo, and Wonosobo did by developing a variety of non-timber business, in Magelang conservation of forest resources. Development of the fisheries subsector in Kebumen improving the marketing, in Purworejo increase fisheries production, in Magelang managing and marketing of fisheries production, in Wonosobo provision of adequate infrastructure.
\end{abstract}

Keywords: Minimum Requirements Technique, Agricultural Sub Sector, Kedu Residency

Abstrak: Penelitian ini bertujuan (1) mengidentifikasi sub sektor pertanian basis dan
non basis di Karesidenan Kedu (2) mengembangkan sub sektor pertanian basis di
Karesidenan Kedu. Hasil penelitian sub sektor tanaman bahan makanan basis di
Kebumen, Magelang, Wonosobo, Temanggung. Sub Sektor Tanaman Perkebunan
basis di Kebumen, Purworejo, Magelang, Temanggung. Sub Sektor Peternakan basis
di Kebumen, Magelang, Wonosobo, Temanggung. Sub Sektor Kehutanan basis di
Kebumen, Purworejo, Magelang, Wonosobo. Sub Sektor Perikanan basis di Kebumen,
Purworejo, Magelang, Wonosobo. Sub sektor tanaman bahan makanan non basis di
Purworejo, sub sektor tanaman perkebunan di Wonosobo, sub sektor peternakan di
Purworejo, sub sektor kehutanan di Temanggung, dan sub sektor perikanan di
Temanggung. Perkembangan sub sektor tanaman bahan makanan di Kebumen dengan
memaksimalkan produksi, di Magelang dilakukan pengembangan Agribisnis, di
Wonosobo dilakukan pengolahan dan pemasaran hasil produksi, di Temanggung
dilakukan pemasaran hasil produk pertanian. Perkembangan sub sektor perkebunan di
Kebumen yaitu pengembangan SDM yang terlatih, di Purworejo meningkatkan
pemasaran hasil perkebunan, di Magelang pengembangan kawasan konservasi, di 
Temanggung meningkatkan pemasaran dan pengolahan pasca panen. Perkembangan sub sektor peternakan di Kebumen memberikan penguatan modal, di Magelang peningkatan produktivitas melalui perbaikan mutu genetik, di Wonosobo menganggarkan Dana revolsin, di Temanggung peningkatan nilai tambah peternakan. Perkembangan sub sektor kehutanan di Kebumen, Purworejo, dan Wonosobo dengan mengembangkan aneka usaha non kayu, di Magelang konservasi sumber daya hutan. Perkembangan sub sektor perikanan di Kebumen meningkatkan pemasaran, di Purworejo peningkatan produksi perikanan tangkap, di Magelang manajemen dan pemasaran perikanan, di Wonosobo penyediaan infrastuktur.

Kata Kunci: Minimum Requirements Technique, Sub Sektor Pertanian, Karesidenan Kedu

\section{PENDAHULUAN}

Pembangunan merupakan suatu proses yang harus dipandang secara multidimensional yang mencakup berbagai perubahan mendasar atas struktur sosial, sikap-sikap masyakarat dan institusi-institusi (kelembagaan) nasional (Todaro dan Smith, 2006). Pembangunan tidak hanya berlangsung di setiap aspek (struktur sosial, sikap hidup masyarakat, dan kelembagaan nasional), tetapi juga terjadi di setiap tingkatan baik itu tingkatan nasional maupun tingkatan daerah. Pembangunan ditingkat daerah atau ditingkat yang lebih kecil, akan memberikan hasil yang mampu mendukung pembangunan yang di lakukan di wilayah yang lebih besar. Menurut Syahriani (2001), dalam kerangka pembangunan ekonomi daerah, desentralisasi ekonomi bukan sekedar pembagian keuangan antara pemerintah pusat dengan daerah, namun harus diterjemahkan dalam tiga aspek perubahan yakni pendaerahan pengelolan pembangunan ekonomi, swastanisasi perencanaan pelaksanaan pembangunan ekonomi, dan organisasi serta kelembagaan pembangunan ekonomi juga harus mengalami perubahan yang lebih baik.

Sektor pertanian merupakan salah satu dari kesembilan sektor perekonomian yang memainkan peranan penting di negara sedang berkembang. Beberapa peran sektor pertanian dalam pembangunan ekonomi antara lain 1) sebagai penyedia pangan, 2) sebagai sumber tenaga kerja bagi perekonomian lain, 3) sebagai sumber capital bagi pertumbuhan ekonomi modern 4) sebagai sumber devisa negara, dan 5) masyarakat pedesaan merupakan pasar bagi produk yang dihasilkan dari sektor industri di perkotaan (Gillis et al, 1992).

Tabel 1 Nilai dan Kontribusi PDRB menurut Lapangan Usaha ADHK 2000 di Eks Karesidenan Kedu Tahun 2013 (Dalam Jutaan Rupiah)

\begin{tabular}{rlrr}
\hline No & \multicolumn{1}{c}{ Sektor Perekonomian } & \multicolumn{2}{c}{ PDRB } \\
\cline { 3 - 4 } & & $\mathbf{5 . 3 3 9 . 2 0 7 , 1 9}$ & Kontribusi (\%) \\
\hline 1 & Pertanian & $493.021,50$ & $\mathbf{3 2 , 1 1}$ \\
2 & Pertambangan dan Penggalian & $2.381 .321,32$ & 2,96 \\
3 & Industri Pengolahan & $115.681,12$ & 14,32 \\
4 & Listrik, Gas, dan Air Bersih & $1.048 .516,69$ & 0,70 \\
5 & Bangunan & $2.486 .400,46$ & 6,31 \\
6 & Perdagangan, Hotel dan Restoran & $979.250,14$ & 14,95 \\
7 & Pengangkutan dan Komunikasi & $766.448,61$ & 5,89 \\
8 & Keuangan, Persewaan dan Jasa & & 4,61 \\
& Perusahaan & $3.019 .569,42$ & 18,16 \\
9 & Jasa-jasa & $14.450 .401,04$ & 100.00 \\
\hline Total & & &
\end{tabular}

Sumber : PDRB Kabupaten Kebumen, Purworejo, Wonosobo, Temanggung, dan Magelang Tahun 2013, diolah 
Tabel 2. Nilai PDRB Sektor Pertanian ADHK Tahun Dasar 2000 di Kabupaten yang Tergabung Dalam Eks Karesidenan Kedu

\begin{tabular}{lrrrrr}
\hline \multirow{2}{*}{ Kabupaten } & \multicolumn{5}{c}{ Tahun } \\
\cline { 2 - 6 } & \multicolumn{1}{c}{2009} & \multicolumn{1}{c}{2010} & \multicolumn{1}{c}{2011} & \multicolumn{1}{c}{2012} & \multicolumn{1}{c}{2013} \\
\hline Kebumen & $1,075,552.43$ & $1,098,154.32$ & $1,130,531.58$ & $1,198,584.02$ & $1,195,787.49$ \\
Purworejo & $989,189.30$ & $1,026,366.73$ & $1,049,982.55$ & $1,086,788.53$ & $1,119,180.85$ \\
Magelang & $1,127,359.19$ & $1,145,120.48$ & $1,142,912.87$ & $1,179,258.55$ & $1,213,076.08$ \\
Wonosobo & $883,489.58$ & $918,463.99$ & $947,303.33$ & $977,489.44$ & $1,001,035.61$ \\
Temanggung & $720,499.20$ & $746,849.38$ & $752,103.97$ & $790,558.82$ & $810,127.15$ \\
\hline Total PDRB Sektor & & & & & \\
Pertanian & $4,796,089.70$ & $4,934,954.90$ & $5,022,834.30$ & $5,232,679.36$ & $5,339,207.19$ \\
\hline
\end{tabular}

Sumber :PDRB Kabupaten Kebumen, Purworejo, Wonosobo, Temanggung, dan Magelang Tahun 2013.

Selain itu sektor pertanian juga merupakan sumber modal yang utama bagi pertumbuhan ekonomi, sehingga dapat dikatakan bahwa sektor pertanian juga berperan dalam mengurangi tingkat pengangguran masyarakat. Apabila pemerintah memperhatikan kesejahteraan masyarakatnya, salah satu caranya adalah dengan meningkatkan kesejahteraan masyarakatnya yang hidup di sektor pertanian (Arsyad, 1992).

Eks Karesidenan Kedu merupakan pembagian administratif di Provinsi Jawa Tengah yang terdiri dari Kabupaten Kebumen, Purworejo, Wonosobo, Temanggung, dan Magelang.Kelima kabupaten tersebut memiliki potensi sektor pertanian yang cukup menonjol. Hal ini terbukti dengan besarnya sumbangan sektor pertanian di Eks Karesidenan Kedu yang memiliki kontribusi paling besar dibandingkan dengan sektor ekonomi lainnya. (Tabel 1).

Namun apabila dilihat PDRB antara tahun 2009-2013, kontribusi sektor pertanian dimasing-masing Kabupaten berfluktuasi dengan kecenderungan meningkat dari tahun ke tahun (Tabel 2.). Kondisi ini menunjukkan bahwa sektor pertanian memiliki potensi untuk dikembangkan di masa mendatang. Naik turunnya nilai PDRB dipengaruhi oleh produksi yang dihasilkan dari setiap komoditas sektor pertanian. Sektor pertanian terbagi menjadi 5 sub sektor di dalamnya yaitu sub sektor tanaman bahan makanan, sub sektor tanaman perkebunan, sub sektor peternakan dan hasilhasilnya, sub sektor kehutanan, dan sub sektor perikanan. Kontribusi dari sub sektor tersebut terhadap perekonomian di Eks Karesidenan Kedu tentu saja berbeda-beda. Kontribusi subsektor tabama sebesar 22,00\%; perkebunan $3,98 \%$, peternakan $4,11 \%$; kehitanan $1,31 \%$, dan kehutanan 0,71\% (PDRB Kabupaten Kebumen, Purworejo, Wonosobo, Temanggung, dan Magelang Tahun 2013). Kabupaten yang tergabung dalam Eks Karesidenan Kedu, belum memusatkan sub sektor pertanian tersebut sebagai pusat pertumbuhan ekonomi. Oleh karena itu, perlu dilakukan identifikasi sub sektor pertanian di masing-masing Kabupaten untuk menciptakan pertumbuhan ekonomi yang tinggi di daerah tersebut. Hasil identifikasi akan menunjukkan sub sektor apa yang termasuk dalam sub sektor basis dan non-basis, sehingga menjadikan sub sektor basis tersebut sebagai sub sektor "unggulan" daerah, sub sektor yang mampu berkembang dan bersaing dengan daerah lain serta mampu melakukan ekspor ke daerah lain. Penelitian ini bertujuan untuk mengidentifikasi sub sektor pertanian basis dan non basis di Eks Karesidenan Kedu. menggunakan Minimum Requirements Technique (MRT) serta untuk mengembangkan sub sektor pertanian basis di Eks Karesidenan Kedu.

\section{METODE PENELITIAN}

\section{Metode Dasar Penelitian}

Metode dasar penelitian adalah metode deskriptif analisis.

\section{Penentuan Lokasi}

Penentuan Lokasi penelitian dilakukan secara sengaja (purposive). Penelitian dilakukan di Eks Karesidenan Kedu yang terdiri dari 5 Kabupaten yaitu Kabupaten Kebumen, Purworejo, Magelang, Wonosobo, dan Temanggung. Pemilihan lokasi tersebut didasarkan dengan melihat PDRB sektor pertanian Eks Karesidenan Kedu tahun 2013. Sektor pertanian Eks Karesidenan Kedu 
Dinan A., Agustono, Nuning S.: Identifikasi Sub Sektor Pertanian ...

Tabel 3. Hasil Identifikasi Sub Sektor Pertanian Basis dan Non Basis Pada Kabupaten di Eks Karesidenan Kedu Berdasarkan Minimum Requirements Technique (MRT) Tahun 2009 - 2013

\begin{tabular}{|c|c|c|c|c|c|c|}
\hline \multirow{2}{*}{ No } & \multirow{2}{*}{$\begin{array}{l}\text { Sub Sektor } \\
\text { Pertanian }\end{array}$} & \multicolumn{5}{|c|}{ Identifikasi Basis dan Non-Basis } \\
\hline & & Kebumen & Purworejo & Magelang & Wonosobo & Temanggung \\
\hline 1 & $\begin{array}{l}\text { Tanaman Bahan } \\
\text { Makanan }\end{array}$ & Basis & Non Basis & Basis & Basis & Basis \\
\hline 2 & $\begin{array}{l}\text { Tanaman } \\
\text { Perkebunan }\end{array}$ & Basis & Basis & Basis & Non Basis & Basis \\
\hline 3 & Peternakan & Basis & Non Basis & Basis & Basis & Basis \\
\hline 4 & Kehutanan & Basis & Basis & Basis & Basis & Non Basis \\
\hline 5 & Perikanan & Basis & Basis & Basis & Basis & Non Basis \\
\hline
\end{tabular}

Sumber : Hasil Analisis Data

dibandingkan dengan Eks Karesidenan lain yang ada di Provinsi Jawa Tengah, termasuk Eks Karesidenan yang memiliki kontribusi sektor pertanian yang paling besar dalam perekonomian daerah yaitu sebesar 29,93\% (PDRB Kabupaten/Kota Se-Jawa Tengah Tahun 2013). Hal ini menunjukkan bahwa sektor pertanian di Eks Karesidenan Kedu merupakan kegiatan perekonomian yang utama. Besarnya kontribusi sektor pertanian tersebut diharapkan mampu mencapai pertumbuhan ekonomi yang tinggi.

\section{Jenis dan Sumber Data}

Data yang digunakan pada penelitian ini adalah data sekunder yang diperoleh dari Badan Pusat Statistik Kabupaten Kebumen, Purworejo, Magelang, Wonosobo, dan Temanggung. Selain itu RPJMD masing-masing Kabupaten.

\section{Metode Pengumpulan Data}

Metode pengumpulan data dalam penelitian ini adalah dokumenrasi, wawancara, dan observasi. Dokumentasi dilakukan dengan membaca, memahami, dan mempelajari dokumen-dokumen yang ada di intansi atau lembaga yang terkait dengan penelitian ini. Wawancara dilaksanakan dengan melakukan tanya jawab secara langsung dengan Pemerintah Daerah terkait dengan hasil identifikasi sub sektor pertanian. Observasi dilakukan dengan melakukan pengamatan langsung ke lokasi penelitian.

\section{Metode Analisis Data}

Identifikasi Sub Sektor Pertanian Basis dan Non-Basis Berdasarkan Pendekatan Minimum Requirements Technique (MRT)

Dalam model ekonomi basis, perekonomian terbagi menjadi dua yaitu sektor basis dan non basis. Sektor basis adalah sektor yang mengekspor barang dan jasa ke tempat di luar perbatasan perekonomian masyarakat atau memasarkan barang dan jasa kepada orang yang datang dari luar batas perekonomian masyrakat yang bersangkutan Sektor non-basis adalah sektor-sektor yang mnyediakan barang dan jasa yang dibutuhkan oleh orang-orang dalam batas perekonomian masyarakat yang bersangkutan (Tarigan, 2005). Untuk mengidentifikasi sektor basis dan non-basis, alat analisis yang dapat digunakan antara lain Location Quotient/LQ (Sambidi 2008, Miller and Petter 2009, Quintero 2007), Analisis Shift Share (Sambidi, 2008) dan Minimum Requirements Technique/MRT (Dinc, 2002). Identifikasi sub sektor pertanian basis dan nonbasis dalam penelitian ini menggunakan Minimum Requirements Technique (MRT). Minimum Requirements Technique (MRT) digunakan untuk mengetahui sektor basis dan non-basis dalam lingkup antar daerah. Apabila hasil perhitungan sub sektor memiliki angka minimum di suatu daerah, maka sub sektor tersebut dinyatakan sebagai sub sektor nonbasis. Sedangkan daerah lain yang memiliki hasil perhitungan di atas angka minimum, sub sektor tersebut dinyatakan sebagai sub sektor basis. Minimum Requirements Technique (MRT) dapat ditulis dengan rumus (Dinc, 2002) :

$$
\text { Share }=\frac{E_{\text {ir }}}{E_{r}}
$$

$E_{\text {ir }}$ adalahPDRB sub sektor pertanian i di wilayah $\mathrm{r}$

$E_{r}$ adalah Total PDRB sub sektor pertanian di wilayah $\mathrm{r}$

I adalah 5 sub sektor pertanian sub sektor tanaman bahan makanan, sub sektor tanaman 
perkebunan, sub sektorpeternakan dan hasilhasilnya, sub sektor kehutanan,dan sub sektor perikanan

$\mathrm{r}$ adalah 5 Kabupaten (Kabupaten Kebumen, Purworejo, Wonosobo, Magelang, Temanggung).

\section{HASIL DAN PEMBAHASAN}

Identifikasi Sub Sektor Pertanian Basis dan Non Basis Berdasarkan Pendekatan Minimum Requirements Technique (MRT)

Adapun hasil analisis Minimum Requirements Technique (MRT) untuk mengidentifikasi sub sektor pertanian basis dan non basis di masingmasing Kabupaten yang tergabung dalam Eks Karesidenan Kedu dapat dilihat pada Tabel 3. Berdasarkan hasil analisis MRT diketahui bahwa :

\section{Kabupaten Kebumen}

Berdasarkan hasil perhitungan MRT, sub sektor basis di Kabupaten Kebumen meliputi sub sektor tanaman bahan makanan, perkebunan, peternakan, kehutanan, dan perikanan. Sub sektor tanaman bahan makanan di Kabupaten Kebumen sendiri memiliki kontribusi yang paling besar dalam penyusunan PDRB sektor pertanian. Hasil produksi tanaman bahan makanan merupakan hasil produksi terbesar di antara komoditas pangan lainnya di Kabupaten Kebumen.

Komoditas tanaman padi di Kabupaten Kebumen merupakan penyangga pangan pokok di Jawa Tengah. Nilai produksi padi (padi sawah dan padi gogo) pada tahun 2013 sebesar $542.757,36$ (juta rupiah). Luas lahan yang digunakan untuk usahatani tanaman pangan dan hortikultura sekitar 67,377 Ha (52,59\%). Lahan sawah yang dimiliki oleh Kabupaten Kebumen diairi oleh dua waduk besar di Kabupaten Kebumen yaitu Waduk Sempor dan Waduk Wadaslintang. Pemerintah Kabupaten Kebumen melakukan pemanfaatan lahan secara maksimal agar jumlah produksi yang dihasilkan oleh komoditas tanaman bahan makanan dan hortikultura selalu mengalami peningkatan dari tahun ke tahun.

Sub sektor tanaman perkebunan mengalami peningkatan pertumbuhan hampir setiap tahunnya. Pertumbuhan tersebut disebabkan karena adanya peningkatan produksi hampir seluruh tanaman perkebunan yang ada di Kabupaten Kebumen. Pada tahun 2013 produksi tanaman perkebunan di Kabupaten Kebumen mengalami peningkatan dari tahun sebelumnya sebesar 59.928,91 ton menjadi 61.475 ton atau sekitar 2,5\% persen. Komoditas perkebunan yang dijadikan sebagai prioritas oleh Pemerintah Kabupaten Kebumen meliputi kelapa (sayur dan deres), cengkeh, kopi, tembakau, tebu, lada dan pandan. Prospek pengembangan kawasan perkebunan di Kabupaten Kebumen sangat baik terutama untuk jenis komoditas prioritas yang memiliki nilai jual tinggi. Dukungan untuk kegiatan pengembangan kawasan dan produksi perkebunan, diperlukan adanya dukungan sumber daya manusia pertanian yang terlatih dalam penerapan teknologi seperti sekolah lapang, bimbingan teknis, pelatihan dan pendidikan pertanian.

Pertumbuhan ekonomi pada sub sektor peternakan di Kabupaten Kebumen mengalami peningkatan dari tahun ke tahun, walaupun populasi ternak sapi dan kerbau mengalami penurunan. Peningkatan tersebut disumbang oleh peningkatan produksi daging dan seluruh pemotongan baik yang tercatat maupun tidak tercatat dari komoditas kerbau, ayam buras, dan babi. Peningkatan jumlah populasi ternak akan menaikkan tingkat konsumsi hasil ternak masyarakat Kabupaten Kebumen. Pemerintah Kabupaten Kebumen memberikan penguatan modal peternakan melalui Program Kredit Ketahanan Pangan Energi (KKPE) serta Kredit Usaha Peternakan Sapi (KUPS) dan Sarjana Membangun Desa (SMD) untuk mencapai swasembada daging sapi nasional.

Sub sektor kehutanan memiliki peran yang aktif bagi kehidupan sehari-hari penduduk Kabupaten Kebumen yaitu sebagai penyedia bahan baku pembuatan peralatan rumah tangga seperti kursi, mebel, lemari dan lain sebagainya. Komoditas kayu jati di Kabupaten Kebumen paling besar perannya dalam pembentukan PDRB sub sektor kehutanan.Hal ini dikarenakan kayu jati memiliki banyak manfaat bagi masyarakat Kabupaten Kebumen untuk pembuatan peralatan rumah tangga dan memiliki nilai produksi maupun nilai jual yang tinggi. Prospek pengembangan Kabupaten Kebumen dalam urusan kehutanan yakni mengembangkan aneka usaha non kayu sekitar hutan dan mengembangkan hutan rakyat. 
Sub sektor perikanan memiliki peran aktif dalam memenuhi kebutudan dan kehidupan sehari-hari bagi masyarakat Kabupaten Kebumen dan sekitarnya. Kegiatan budidaya perikanan di Kabupaten Kebumen didukung dengan potensi sumberdaya alam yang ada yaitu letak geografis dari Kabupaten Kebumen yang berbatasan langsung dengan Samudra Hindia dan terdapat 2 waduk besar yaitu Waduk Sempor dan Waduk Wadaslintang. Produksi pada sub sektor perikanan di Kabupaten Kebumen mengalami pertumbuhan dari tahun ke tahun. Pada tahun 2013, pertumbuhan sub sektor perikanan ini sebesar 10,08\% dari tahun sebelumnya. Dengan demikian, program yang dilakukan Pemerintah Kabupaten dalam mengembangkan sub sektor perikanan adalah meningkatkan hasil pemasaran dan pengelolaan pasca panen.

\section{Kabupaten Purworejo}

Berdasarkan hasil perhitungan MRT, sub sektor basis di Kabupaten Purworejo meliputi sub sektor tanaman perkebunan, sub sektor kehutanan dan sub sektor perikanan. Penentuan sub sektor basis tersebut, di dasarkan pada nilai share dimana nilai share dari ketiga sub sektor tersebut di Kabupaten Purworejo memiliki nilai share di atas angka minimum sub sektor tanaman perkebunan di Kabupaten Wonosobo, sub sektor kehutanan dan sub sektor perikanan di Kabupaten Temanggung.

Perkebunan yang dimanfaatkan di Kabupaten Purworejo adalah perkebunan rakyat. Komoditas perkebunan unggulan di Kabupaten Purworejo adalah kelapa. Kelapa banyak dibudidayakan oleh masyarakat Kabupaten Purworejo karena, buah kelapa ini selain dimanfaatkan dalam buah asli, juga dimanfaatkan buah daging (kopra) untuk dijadikan sebagai bahan baku pembuatan minyak kelapa. Selain itu, kelapa deres di Kabupaten Purworejo juga mempunyai produksi yang banyak dan digunakan sebagai bahan baku pembuatan gula merah. Gula merah dan minyak kelapa yang dihasilkan dari Kabupaten Purworejo nantinya akan digunakan untuk memenuhi kebutuhan lokal di daerah sekitar dan sisanya akan di ekspor ke wilayah lain seperti Kabupaten Wonosobo, Kabupaten Kulonprogo, dan sekitarnya. Prospek pengembangan kawasan perkebunan di Kabupaten Purworejo sangat baik terutama untuk jenis-jenis komoditas yang mempunyai nilai jual yang cukup tinggi seperti kelapa, melinjo, dan tebu.

Besarnya peranan sub sektor kehutanan di Kabupaten Purworejo didukung oleh produksi komoditas-komoditas sub sektor kehutanan. Komoditas kehutanan yang memiliki jumlah produksi tinggi adalah kayu albasia. Kayu ini dimanfaatkan oleh masyarakat Kabupaten Purworejo sebagai bahan bangunan dan bahan baku dasar pabrik serta industri.Prospek pengembangan sub sektor kehutanan di Kabupaten Purworejo untuk menghasilkan produk yang berkualitas dan berkuantitas tinggi maka melakukan beberapa program antara lain Pelestarian dan pengelolaan hutan dan lahan dengan fokus pada peningkatan partisipasi masyarakat dalam pembudidayaan kehutanan, dan Peningkatan pemanfaatan hasil hutan dengan fokus pada pengembangan produk-produk kehutanan non kayu.

Prospek pengembangan kegiatan perikanan budidaya di Kabupaten Purworejo sangat besar karena didukung dengan potensi sumber daya alam yang ada yaitu letak geografis dari Kabupaten Purworejo bagian selatan yang berbatasan langsung dengan laut. Perikanan laut di Kabupaten Purworejo didukung dengan banyaknya nelayan pada tahun 2013 sebanyak 617 orang dan dari tahun ke tahun selalu mengalami peningkatan. Besarnya potensi perikanan di Kabupaten Purworejo, maka Pemerintah Kabupaten Purworejo melakukan perencanaan starategi yakni Peningkatan produksi perikanan tangkap dan pendapatan nelayan dengan fokus pada penyediaan sarana dan prasarana produksi dan peningkatan akses permodalan.

\section{Kabupaten Magelang}

Berdasarkan hasil perhitungan MRT, sub sektor basis di Kabupaten Magelang meliputi sub sektor tanaman bahan makanan, sub sektor perkebunan, sub sektor peternakan, sub sektor kehutanan, dan sub sektor perikanan. Pertanian merupakan pendukung pertumbuhan ekonomi Kabupaten Magelang karena, sesuai dengan kondisi Kabupaten Magelag sebagai daerah agraris. Dilihat dari keadaan alam, ketersediaan sarana dan prasarana juga letak geografis yang sangat strategi. 
Sub sektor tanaman bahan makanan di Kabupaten Magelang merupakan sumber utama produksi komoditas pangan dan hortikultura di Jawa Tengah sehingga produktivitas tanaman pangan khususnya padi selalu ditingkatkan. Komoditas unggulan tanaman pangan di Kabupaten Magelang adalah Padi. Dalam rangka mengembangkan Agribisnis Kabupaten Magelang, maka telah dibangun 2 sub terminal Agribisnis (STA) yaitu di Desa Sewutan Kecamatan Dukun dan Desa Ngablak Kecamatan Ngablak serta Pasar Buah Salah Nglumut di Desa Sucen Kecamatan Salam. Buah salak di Kabupaten Magelang sudah terkenal sebagai komoditas buah unggulan.

Komoditas perkebunan yang terdapat di Kabupaten Magelang mencakup tembakau, kapuk, kelapa, kopi, teh, cengkeh, tebu, dan kapulaga.Di bidang perkebunan ini, masyarakat Kabupaten Magelang mayoritas mengandalkan budidaya tanaman tembakau dan tebu. Selain tanaman tembakau dan tebu, Kabupaten Magelang juga menghasilkan kelapa. Tanaman tebu di Kabupaten Magelang dimanfaatkan sebagai bahan baku pembuatan gula pasir. Tanaman tebu ini biasanya di kirim ke wilayah lain untuk bahan baku pembuatan gula pasir di pabrik-pabrik sekitar Kabupaten Magelang seperti dikirim ke daerah D.I Yogyakarta di Pabrik Gula Madukismo sebagai bahan baku pembuatan gula pasir. Kabupaten Magelang sebagai supplier tanaman tebu bagi pabrikpabrik gula dari wilayah sekitar. Prospek pengembangan kawasan perkebunan di Kabupaten Magelang sangat baik terutama untuk jenis-jenis komoditas yang mempunyai nilai jual tinggi seperti tembakau, kopi, dan tebu.Untuk meningkatkan dan mengembangkan potensi tanaman perkebunan maka dilakukan perencanaan salah satunya adalah pengembangan kawasan konservasi dalam mendukung peningkatan produksi hutan dan lahan.

Produksi ternak di Kabupaten Magelang diperkirakan sama dengan jumlah ternak yang dipotong ditambah perubahan stok populasi ternak dan ekspor. Populasi ternak di Kabupaten Magelang mengalami peningkatan setiap tahunnya.Pada tahun 2013, populasi ternak yang mengalami peningkatan paling banyak adalah sapi perah sebesar 212,55\%. Peningkatan produksi daging, susu dan telor meningkat seiring dengan meningkatnya jumlah permintaan. Pengembangan peternakan Kabupaten Magelang didukung oleh potensi wilayah untuk pengembangan ternak besar maupun ternak kecil serta ternak unggas. Adanya peningkatan populasi ternak dan peningkatan produksi hasil ternak, maka Pemerintah Kabupaten Magelang membuat perencanaan strategi yakni meningkatkan populasi, produksi dan produktivitas melalui perbaikan mutu genetik, perbaikan pakan, perawatan, kesehatan, sarana produksi dan menjalin kemitraan usaha.

Pembangunan kehutanan di Kabupaten Magelang sudah dilaksanakan mulai tahun 2004 sampai dengan sekarang sudah mengalami berbagai peningkatan dan semakin berkurangnya lahan kritis. Pengolahan hasil hutan rakyat digunakan sebagai bahan baku industri pengolahan kayu dan furniture (peralatan rumah tangga) seperti mebel, kursi, meja dan lemari.Pengolahan hasil produksi hutan rakyat di Kabupaten Magelang dapat mendorong perkembangan kegiatan industri pengolahan terutama industri kayu sehingga diharapkan adanya multipler effect. Lahan kritis di Kabupaten Magelang sudah semakin berkurang dan berbagai kegiatan di sub sektor kehutanan sudah mulai meningkat dari tahun ke tahun.Berkaitan dengan hal itu, ada beberapa program yang dilakukan oleh Pemerintah Kabupaten Magelang untuk terus meningkatkan produksi di bidang kehutanan yaitu rehabilitasi hutan dan lahan, perlindungan dan konservasi sumber daya hutan, dan peningkatan produksi kehutanan.

Perikanan di Kabupaten Magelang berpotensi untuk dikembangkan dalam rangka meningkatkan pendapatan masyarakat.Potensi tersebut meliputi budidaya kolam dan perairan umum.Strategi yang dilakukan dalam pembangunan urusan perikanan di Kabupaten Magelang yakni Meningkatkan populasi, produksi dan produktifitas perikanan. Pemerintah Kabupaten Magelang melaksanakan prioritas program pembangunan perikanan antara lain Program pengembangan budidaya perikanan, program optimalisasi pengelolaan dan pemasaran produksi perikanan, dan program pengembangan kawasan budidaya air tawar. 


\section{Kabupaten Wonosobo}

Berdasarkan hasil perhitungan MRT, sub sektor basis di Kabupaten Wonosobo meliputi sub sektor tanaman bahan makanan, sub sektor peternakan, sub sektor kehutanan, dan sub sektor perikanan. Penentuan sub sektor basis tersebut, di dasarkan pada nilai share dimana nilai share keempat sub sektor tersebut di Kabupaten Wonosobo memiliki nilai share di atas angka minimum sub sektor tanaman bahan makanan dan sub sektor peternakan di Kabupaten Purworejo, sub sektor kehutanan dan sub sektor perikanan di Kabupaten Temanggung.

Sub sektor tanaman bahan makanan di Kabupaten Wonosobo berpotensi karena menghasilkan produksi dalam jumlah besar. Luas lahan sawah yang dimiliki Kabupaten Wonosobo adalah 16.040 Ha. Pertambahan penduduk yang terjadi di Kabupaten Wonosobo merupakan penyebab utama semakin banyaknya jumlah permintaan terhadap tanaman pangan sebagai sumber energi utama untuk memenuhi kebutuhan hidup seharihari.Komoditas sub sektor tanaman bahan makanan yang dijadikan sebagai unggulan meliputi tanaman padi, jagung, ubi kayu, dan ubi jalar. Sedangkan komoditas sayur-sayuran yang menghasilkan produksi dalam jumlah besar adalah labu siam, sedangkan komoditas buah-buahan yang menghasilkan produksi dalam jumlah besar adalah salak. Pada tahun 2013 produksi komoditas sub sektor tanaman bahan makanan meningkat dari tahun sebelumnya sekitar 20,5\%. Berkaitan dengan perkembangan ini, maka strategi untuk mencapai kualitas dan kuantitas dalam pembangunan pertanian kedepan diarahkan pada pengembangan agribisnis yang mencakup kegiatan pengolahan pasca panen, pemasaran hasil pertanian, pemilihan bibit unggul, dan penyediaan saprodi.

Populasi ternak di Kabupaten Wonosobo selalu mengalami peningkatan setiap tahunnya dari tahun 2009-2013. Peningkatan ini seiring dengan semakin meningkatnya jumlah penduduk yang mengusahakan karena untuk memenuhi kebutuhan pangan. Produksi yang dihasilkan dari ternak tersebut antara lain daging, susu, dan telur. Produksi daging, susu, dan telur di Kabupaten Wonosobo selalu mengalami peningkatan karena semakin banyaknya jumlah permintaan. Prospek pengembangan sub sektor peternakan di Kabupaten Wonosobo sangat baik terlihat dari banyaknya populsi ternak dan banyaknya produksi (susu, daging dan telur) yang dihasilkan. Berkaitan dengan itu, pemerintah Kabupaten Wonosobo secara rutin menganggarkan dana revolsin untuk peternakan sapi potong, sapi perah, kambing, ayam ras petelur, ayam ras pedaging, itik dan burung puyuh.luar wilayah Kabupaten Wonosobo.

Hutan yang dimanfaatkan pada sub sektor kehutanan di Kabupaten Wonosobo adalah hutan rakyat. Sub sektor kehutanan di Kabupaten Wonosobo berperan bagi kehidupan sehari-hari yaitu sebagai sub sektor penyedia peralatan rumah tangga dan industri pengolahan kayu. Hasil produksi hutan yang khas dari Kabupaten Wonosobo adalah Gondorukem. Prospek sub sektor kehutanan di Kabupaten Wonosobo baik. Berkaitan dengan hasil produksi hutan rakyat maka pemerintah Kabupaten Wonosobo melakukan perencanaan salah satunya adalah pengembangan dan diversifikasi penanaman jenis hutan sehingga memungkinkan untuk diambil hasil non kayu seperti buah dan getah, serta pengolahan hasil hutan agar memiliki nilai ekonomi yang lebih tinggi.

Prospek pengembangan kegiatan budidaya perikanan sangat besar di Kabupaten Wonosobo karena didukung dengan potensi sumber daya alam yang ada yaitu letak geografis dari Kabupaten Wonosobo sendiri terdapat waduk yang sangat luas yaitu Waduk Wadaslintang, sehingga strategi yang dilakukan pemerintah Kabupaten Wonosobo adalah rencana penyediaan infrastruktur yang memadai baik lembaga penyuluhan, lembaga pengkajian, infrastruktur yang mendukung seperti jalan dan kelembagaan kelompok pembudidaya perikanan dan koperasi perikanan serta pasar ikan. Pengembangan kawasan peruntukan perikanan dilakukan dengan mengembangkan budidaya air tawar, dan meningkatkan sarana prasarana pendukung kawasan perikanan.

\section{Kabupaten Temanggung}

Berdasarkan hasil perhitungan MRT, sub sektor basis di Kabupaten Temanggung meliputi sub sektor tanaman bahan makanan, sub sektor perkebunan, dan sub sektor peternakan. Penentuan sub sektor basis tersebut, didasarkan 
pada nilai share dimana nilai share dari ketiga sub sektor tersebut di Kabupaten Temanggung memiliki nilai share di atas angka minimum sub sektor tanaman bahan makanan di Kabupaten Purworejo, sub sektor tanaman perkebunan di Kabupaten Wonosobo, dan sub sektor peternakan di Kabupaten Purworejo.

Sub sektor tanaman bahan makanan di Kabupaten Temanggung memberikan andil sebesar $20,50 \%$ pada tahun 2015 . Komoditas yang memberikan sumbangan besar dalam sub sektor tanaman bahan makanan adalah tanaman padi. Tanaman padi sebagai pemenuhan kebutuhan hidup sehari-hari pangan pokok Kabupaten Temanggung banyak ditanam oleh sebagian masyarakat Temanggung. Kabupaten Temanggung memiliki potensi pada sub sektor tanaman bahan makanan dan hortikultura ini karena produksi yang dihasilkan setiap tahunnya rata-rata mengalami peningkatan. Peningkatan hasil produksi ini seiring dengan bertambahnya jumlah penduduk untuk mencukupi kebutuhan sehari-hari dan daerah Temanggung sebagian besar adalah daerah agraris.Berkaitan dengan ini maka untuk mencapai kualitas dan kuantitas pada sub sektor tanaman bahan makanan di Kabupaten Temannggung, pemerintah melaksanakan beberapa program dalam hal pemasaran hasil produk pertanian, penerapan teknologi yang ramah lingkungan, dan penanganan pasca panen.

Sub sektor perkebunan di Kabupaten Temanggung meliputi perkebunan rakyat dan perkebunan besar yang diusahakan perusahaan berbadan hukum. Jenis tanaman perkebunan rakyat yang sangat menonjol adalah tanaman kopi robusta, kopi arabika, dan tembakau. Hasil perkebunan rakyat tersebut terutama kopi robusta, kopi arabika, dan tembakau memiliki nilai produksi yang tinggi di Kabupaten Temanggung, sehingga sudah sewajarnya sub sektor kehutanan di Kabupaten Temanggung menjadi basis. Kabupaten Temanggung terkenal dengan hasil produksi tanaman perkebunannya yaitu kopi dan tembakau. Tanaman tembakau di Kabupaten Temanggung dikirim ke pabrik-pabrik rokok sekitar wilayah Kabupaten Temanggung seperti Pabrik Rokok yang ada di Kudus. Begitu juga tanaman kopi yang dihasilkan dari Kabupaten Temanggung juga sudah mampu melakukan ekspor ke luar wilayah Temanggung dan digunakan sebagai bahan baku pembuatan kopi bubuk. Prospek pengembangan tanaman perkebunan di Kabupaten Temanggung sangat baik terutama untuk jenis komoditas yang memiliki nilai jual tinggi seperti Kopi dan Tembakau. Berkaitan dengan itu, untuk meningkatkan dan mengembangkan potensi tanaman perkebunan dilakukan perencanaan salah satunya dilakukan penelitian dan penyuluhan yang berguna untuk peningkatan kualitas hasil perkebunan dan pengolahan lebih lanjut. Prioritas program pembangunan pertanian terkait dengan sub sektor perkebunan adalah peningkatan pemasaran hasil perkebunan dan pengolahan pasca panen.

Produksi yang dihasilkan dari jenis ternak yang ada di Kabupaten Temanggung meliputi daging, susu, dan telur. Produksi daging, susu, dan telur meningkat seiring dengan meningkatnya jumlah permintaan dan banyaknya penduduk untuk memenuhi kebutuhan sehari-hari. Pada tahun 2013, jumlah produksi daging ternak besar sebanyak 648.650 $\mathrm{kg}$, daging ternak kecil sebanyak $314.705 \mathrm{~kg}$, dan daging unggas sebanyak $8.500 .000 \mathrm{~kg}$. Produksi telur pada tahun 2013 yang dihasilkan oleh ayam ras sebanyak 75.482 .775 butir, ayam kampung sebanyak 23.237.690 butir, itik sebanyak 8.563.129 butir, dan puyuh sebanyak 6.458 .130 butir. Produksi susu yang dihasilkan pada tahun 2013 sebanyak 737.688 liter.

Prospek pengembangan sub sektor peternakan di Kabupaten Temanggung antara lain adalah pemerintah Kabupaten Temanggung meningkatkan produktivitas dan nilai tambah peternakan dengan fokus pada peningkatan kualitas sumber daya manusia dan penyediaan input sarana prasarana peternakan. Selain itu meningkatkan hasil produksi peternakan dan meningkatkan penerapan teknologi modern.Adanya peningkatan hasil produksi dan penerapan teknologi, diharapkan populasi dan hasil produksi ternak setiap tahunnya bertambah. Apabila produksi melimpah, maka akan meningkatkan pendapatan masyarakat di daerah tersebut.

\section{KESIMPULAN}

Berdasarkan Minimum Requirements Technique (MRT) selama Tahun 2009-2013 dihasilkan Sub Sektor Basis Tanaman Bahan Makanan di Kabupaten Kebumen, Kabupaten 
Magelang, Kabupaten Wonosobo, dan Kabupaten Temanggung. Sub Sektor Tanaman Perkebunan di Kabupaten Kebumen, Kabupaten Purworejo, Kabupaten Magelang, dan Kabupaten Temanggung. Sub Sektor Peternakan di Kabupaten Kebumen, Kabupaten Magelang, Kabupaten Wonosobo, dan Kabupaten Temanggung. Sub Sektor Kehutanan di Kabupaten Kebumen, Kabupaten Purworejo, Kabupaten Magelang, dan Kabupaten Wonosobo. Sub Sektor Perikanan di Kabupaten Kebumen, Kabupaten Purworejo, Kabupaten Magelang, dan Kabupaten Wonosobo. Sedangkan Sub Sektor Non Basis Tanaman Bahan Makanan di Kabupaten Purworejo. Sub Sektor Tanaman Perkebunan di Kabupaten Wonosobo. Sub Sektor Peternakan di Kabupaten Purworejo.Sub Sektor Kehutanan di Kabupaten Temanggung. Sub Sektor Perikanan di Kabupaten Temanggung.

Perkembangan sub sektor tanaman bahan makanan di Kabupaten Kebumen dilakukan dengan memaksimalkan produksi agar mengalami peningkatan, di Kabupaten Magelang dilakukan dengan pengembangan Agribisnis di 2 kecamatan, di Kabupaten Wonosobo dilakukan pengolahan hingga pemasaran hasil produksi, di Kabupaten Temanggung dilakukan dengan pemasaran hasil produk pertanian dan penerapan teknologi ramah lingkugan. Perkembangan sub sektor perkebunan di Kabupaten Kebumen dilakukan dengan pengembangan sumber daya manusia pertanian yang terlatih, di Kabupaten Purworejo dilakukan dengan meningkatkan pemasaran hasil perkebunan, di Kabupaten Magelang dilakukan dengan pengembangan kawasan konservasi untuk meningkatkan produksi hutan dan lahan, di Kabupaten Temanggung dilakukan dengan cara meningkatkan pemasaran dan pengolahan pasca panen hasil perkebunan. Perkembangan sub sektor peternakan di Kabupaten Kebumen dilakukan dengan memberikan penguatan modal peternakan, di Kabupaten Magelang peningkatan produksi dan produktivitas melalui perbaikan mutu genetik, di Kabupaten Wonosobo menganggarkan dana revolsin untuk peternakan, di Kabupaten Temanggung dilakukan dengan meningkatkan produktivitas dan nilai tambah peternakan. Perkembangan sub sektor kehutanan di Kabupaten Kebumen, Purworejo, dan Wonosobo dilakukan dengan mengembangkan aneka usaha non kayu, di Kabupaten Magelang dilakukan dengan cara perlindungan dan konservasi sumber daya hutan. Perkembangan sub sektor perikanan di Kabupaten Kebumen dilakukan dengan cara meningkatkan pemasaran hasil perikanan, di Kabupaten Purworejo peningkatan produksi perikanan tangkap dan pendapatan nelayan, di Kabupaten Magelang mengoptimalisasi pengelolaan dan pemasaran produksi perikanan, di Kabupaten Wonosobo penyediaan infrastuktur yang memadai

Oleh karena itu saran yang dapat diberikan (1) Pemerintah Kabupaten Purworejo, Wonosobo dan Temanggung diharapkan lebih memprioritaskan maupun memperlihatkan sub sektor yang tergolong basis, namun tidak mengabaikan sub sektor non basis dengan cara melaksanakan programprogram yang sudah dibuat oleh Dinas terkait dan Pemerintahan Kabupaten seperti pemberian bibit unggul untuk sub sektor tanaman bahan makanan di Kabupaten Purworejo, bantuan ternak dan peningkatan pemasaran hasil ternak pada sub sektor peternakan di Kabupaten Purworejo, penelitian dan penyuluhan yang berguna untuk peningkatan kualitas hasil perkebunan pada sub sektor perkebunan di Kabupaten Wonosobo, mengembangkan usaha non kayu pada sub sektor kehutanan di Kabupaten Temanggung, dan penyediaan infrastruktur pembudidayaan perikanan pada sub sektor perikanan di Kabupaten Temanggung. (2) Dalam rangka pengembangan sub sektor pertanian hal yang terpenting yang harus dilakukan adalah meningkatkan kualitas sumber daya manusia yang bekerja pada sub sektor tersebut dengan cara mengadakan pelatihan, penyuluhan, sekolah lapang, dan pendidikan pertanian.

\section{DAFTAR PUSTAKA}

Arsyad, L. 1992. Ekonomi Pembangunan, Edisi 2. Yogyakarya: STIE YKPN

Badan Pusat Statistik. 2013. Temanggung Dalam Angka 2013. BPS Temanggung.

2013. Kebumen Dalam Angka 2013. BPS Kebumen. 
2013. Purworejo Dalam Angka 2013. BPS Purworejo.

2013. Magelang Dalam Angka

2013. BPS Magelang.

2013. Wonosobo Dalam Angka 2013. BPS Wonosobo.

2014. Jawa Tengah Dalam Angka

2013. BPS Jawa Tengah.

2013. Jawa Tengah Dalam Angka

2013. BPS Jawa Tengah.

2012. Jawa Tengah Dalam Angka 2013. BPS Jawa Tengah.

Badan Pusat Statistik. 2013. Produk Domestik Regional Bruto Kabupaten Temanggung Tahun 2013. Temanggung.

2013. Produk Domestik Regional Bruto Kabupaten Kebumen Tahun 2012. Kebumen.

2013. Produk Domestik Regional Bruto Kabupaten Purworejo Tahun 2013. Purworejo.

2013. Pendapatan Regional Kabupaten Magelang Tahun 2013. Magelang

2013. Produk Domestik Regional Bruto Kabupaten Wonosobo Tahun 2013. Wonosobo.

Badan Pusat Statistika (BPS). 2014. http://www.bps.go.id/. Diakses Pada Tanggal 01 Oktober 2015 Pukul 20.00 WIB
Dinc, M. 2002. Regional and Local Economic Analysis Tools. Washington, DC : The World Bank. Economics of Development. Third Edition. W W Norton \& Company. New York. Miller.

Miller, Ronald E and Peter D. Blair. 2009. Input-Output Analysis Foundation and Extensions, Second Edition. Cambridge University Press : UK.

Quintero, James P. 2007. Regional Economic Development: An Economic Base Study and Shift Share Analysis of Hays Country, Texas. Texas State University.

Rice and Horton. 2010. Analysi of Recent Changes in Arkansas Persona Income: 2007-2009. A Shift Share Approach. Journal of Business Administration online, 9(2): 1-12.

Sambidi, P. 2008. Regional Industry Cluster Analysis for the Gulf Coast Economic Development District. Department of Community and Environmental Planning Houston-Galveston Area Council. Texas

Syahrani, H. A. H. 2001. Penerapan Agropolitan dan Agribisnis dalam Pembangunan Ekonomi Daerah. Jurnal Frontir XXXI. Dinas Pertanian, Bandung.

Tarigan, R. 2005. Perencanaan Pembangunan Wilayah. Jakarta: Bumi Aksara

Todaro, Micheal P dan Smith SP. 2006. Pembangunan Ekonomi. Jakarta: Erlangga. 